\title{
PERAN DUKUNGAN SOSIAL TERHADAP OPTIMISME PADA CANCER SURVIVOR DI RUMAH SAKIT ISLAM KHADIJAH PALEMBANG
}

\author{
${ }^{1}$ Fitrah Jufiah Pratiwi, ${ }^{2}$ Sayang Ajeng Mardhiyah, ${ }^{3}$ Amalia Juniarly \\ ${ }^{1,2,3}$ Program Studi Psikologi FK Universitas Sriwijaya \\ Corresponding author - email : ${ }^{2}$ ajeng_mardhiyah.psi@ fk.unsri.ac.id
}

\begin{abstract}
Abstrak. Tujuan penelitian ini adalah untuk mengetahui peranan dukungan sosial terhadap optimisme pada cancer survivor di Rumah Sakit Islam Siti Khadijah Palembang. Hipotesis pada penelitian ini adalah ada peranan dukungan sosial terhadap optimisme pada cancer survivor di Rumah Sakit Siti Khadijah Palembang. Penelitian ini menggunakan teknik non-probability sampling yaitu sampling jenuh sebanyak 93 cancer survivor di Rumah Sakit Islam Siti Khadijah Palembang. Optimisme dan dukungan sosial cancer survivor diukur dengan skala optimisme dan dukungan sosial, dengan mengacu pada jenis dukungan sosial dari House (Smet, 1994) dan dimensi optimisme dari Seligman (2006). Analisis data menggunakan analisis regresi sederhana. Hasil penelitian menunjukkan dukungan sosial memiliki peranan terhadap optimisme yaitu diperoleh taraf siginifikansi sebesar $0,000(\mathrm{p}<0,05)$ dengan nilai $\mathrm{R}$ square sebesar 0,408 , yang berarti dukungan sosial memiliki peran $40,8 \%$ terhadap optimisme, sedangkan sisanya adalah kontribusi variabel lain.
\end{abstract}

Kata kunci: Cancer Survivor, Dukungan Sosial, Optimisme

\begin{abstract}
The research aims to determine the role of social support to optimism on cancer survivor at Siti Khadijah Islamic Hospital Palembang. The hypothesis of this research has a role of social support to optimism on cancer survivor at Siti Khadijah Islamic Hospital Palembang. The research uses non-probability sampling which is saturated sampling, 93 cancer survivors at Siti Khadijah Islamic Hospital Palembang become the subject. Optimism and social support cancer survivors was measured by the scale of social support and optimism, with reference to the types of social support from House (Smet, 1994) and the dimensions of optimism from Seligman (2006). Data analyzed using simple regression analysis. The results of this research indicate social support has a role to optimism that is obtained a significance level of $0,000(p<0.05)$ with $R$ square value of 0.408 , which means social support has a 40,8\% role to optimism and the remaining 59,2\% was influenced by other factors.
\end{abstract}

Keywords: Cancer Survivor, Optimism, Social Support,

Kanker merupakan penyebab utama kematian kedua di dunia dan menyumbang 8,8 juta kematian pada tahun 2015 (WHO, 2017a). Berdasarkan data dari WHO (2017a) pada tahun 2012 terdapat 14,1 juta kasus baru kanker diseluruh dunia, yang mana sekitar 8,2 juta kasus tersebut menyebabkan kematian dan 82,6 juta orang hidup dengan kanker. Kemudian, pada tahun 2017 diprediksikan hampir 9 juta orang meninggal diseluruh dunia akibat kanker dan akan terus meningkat hingga 13 juta orang per tahun di 2030 (Kemenkes RI, 2017a). 
Demikian halnya dengan permasalahan kanker di Indonesia yang terus mengalami peningkatan, berdasarkan data dari Global Burden Cancer pada tahun 2012 insiden kanker di Indonesia sebesar 134 per 100.00 penduduk, kemudian pada tahun 2013 insiden kanker di Indonesia terjadi pada 347.792 orang (Kemenkes RI, 2015). Sedangkan di provinsi Sumatera Selatan rekapitulasi insiden kanker payudara dan kanker serviks dari tahun 2007 hingga 2016 sebanyak 7.308 kasus (Kemenkes RI, 2017b). Kementrian Kesehatan Republik Indonesia (2015) menyatakan penyakit kanker dapat menyerang semua umur, karena hampir semua kelompok umur penduduk memiliki pravelensi penyakit kanker yang cukup tinggi.

Seseorang yang didiagnosis dengan kanker, dari saat didiagnosis dan berusaha untuk melanjutkan hidup dinamakan dengan cancer survivor. Terdapat tiga fase berbeda yang terkait dengan kelangsungan hidup kanker yaitu mulai dari didiagnosis sampai akhir pengobatan awal, transisi dari pengobatan hingga bertahan hidup yang lebih lama, dan kelangsungan hidup jangka panjang (American Cancer Society, 2015). Orang-orang yang menderita penyakit kanker akan mengalami perubahan dan penurunan fisik serta psikisnya karena harus menyesuaikan diri dengan kondisi yang baru dalam dirinya (Prastiwi, 2012; Lusiatun, Ambar \& Bhisma, 2016). Penelitian Poternoy dan Von Gruenigen (Malpass, dkk., 2017) menjelaskan bahwa penderita kanker secara fisik akan mengalami perubahan yang signifikan, pada saat awal didiagnosis dan selama pengobatan gejala fisik seperti kelelahan, mual, muntah, diare serta nyeri sering terjadi.

Pasien kanker akan menjalani kemoterapi sebagai tahap lanjutan pengobatan, kemoterapi merupakan penggunaan zat kimia untuk perawatan penyakit dan obat-obatan tersebut diberikan melalui injeksi, pil atau sirup yang diminum sedangkan krim yang dioleskan pada kulit (Yudissanta \& Ratna, 2012). Efek kemoterapi dapat membuat tubuh merasakan mual dalam periode yang lama, muntah, kelelahan, pansitopenia, alopecia, penurunan berat badan, perubahan selera makan dan sembelit atau diare (Malpass, dkk., 2017). Selain itu, efek kemoterapi juga dapat membuat rambut rontok, kulit dan kuku menjadi hitam, dan kehilangan berat badan (Hrvey, Dittus \& Elise, 2017).

Tidak hanya penurunan serta perubahan fisik, menurut Kubler-Ross (Lidya, 2013) penderita kanker juga akan mengalami perubahan psikologis, yang terjadi mulai dari saat terdiagnosis kanker yaitu munculnya perasaan-perasaan negatif seperti shock, cemas, marah, protes dan depresi. De Groot (Lusiatun, Madigbo \& Murti, 2016) dalam penelitiannya menyatakan bahwa kanker berpengaruh terhadap kondisi psikologis orang yang mengalaminya untuk mengalami kondisi tertekan atau distress, mengingat pengobatan yang berlangsung lama selalu menjadi masalah bagi cancer survivor terlebih lagi memiliki efek kesakitan yang tinggi dan kekhawatiran terhadap biaya pengobatan yang berdampak pada kondisi yang semakin lemah bahkan depresi.

Sikap optimisme sangat membantu dalam mengatasi kesulitan atau masalah dan membuat individu menginterpretasi secara positif segala kejadian serta pengalaman dalam kehidupannya (Hatifah \& Nirwana, 2014). Optimisme adalah paham keyakinan atas segala sesuatu dari segi yang baik dan menyenangkan, sikap selalu mempunyai harapan yang baik dalam segala hal (Hatifah \& Nirwana, 2014). Individu yang optimis memiliki kecenderungan lebih besar percaya bahwa mereka pada umunya akan mengalami hasil yang baik dalam hidup dan termotivasi untuk mengambil pendekatan proaktif dalam kesehatan mereka (Canaria, dkk., 2016). Berdasarkan keterangan diatas 
peneliti menyimpulkan ketika individu memiliki optimisme untuk sembuh, maka individu akan tetap berusaha untuk melakukan hal-hal untuk mencapai kesembuhan, tidak putus asa, serta memiliki kepastian untuk memandang masa depan.

Beberapa hal yang mempengaruhi cara berpikir optimis seseorang diantaranya dari dalam dirinya sendiri dan diluar dirinya sendiri. Vinacle (Nurtjhajanti \& Ika, 2011) menjelaskan bahwa ada dua faktor yang mempengaruhi pola pikir pesimis-optimisme, yaitu faktor etnosentris (dari luar diri) dan egosentris (dari dalam diri), dan dukungan sosial merupakan salah satu faktor dari luar diri. Menurut hasil penelitian yang dilakukan Wardiyah, Afiyanti dan Budiati (2014) bahwa dukungan sosial yang didapatkan oleh responden (pasien kanker payudara) memberikan manfaat bagi responden untuk mengatasi masalah psikologis, beradaptasi terhadap stres, sehingga dengan adanya dukungan sosial, responden dapat meningkatkan semangat hidup dan akan berdampak pada peningkatan optimisme kesembuhan.

Dukungan sosial menurut Sarafino (2011) adalah tindakan yang benar-benar dilakukan oleh orang lain atau menerima dukungan dan juga mengacu pada perasaan seseorang atau persepsi bahwa kenyamanan, perhatian, dan bantuan tersedia yaitu dukungan yang dirasakan. Faktor yang mempengaruhi dukungan sosial yaitu penerima dukungan, pemberi dukungan dan komposisi dan struktur jaringan sosial (Sarafino, 2011). Lebih lanjut terdapat empat jenis dukungan sosial menurut House (Smet, 1994) yaitu dukungan emosional, dukungan penghargaan, dukungan instrumental dan dukungan informatif.

Friedman (Anggina, Hamzah \& Pandhit, 2010) menyatakan secara lebih spesifik dukungan sosial yang adekuat terbukti dengan menurunnya mortalitas, lebih mudah sembuh dari sakit, fungsi kognitif, fisik dan kesehatan emosi, selain itu pengaruh positif dari dukungan sosial adalah penyesuaian pada kejadian dalam kehidupan yang penuh dengan stres. Dukungan sosial dapat membantu individu berfokus pada aspek dan potensi yang menguntungkan dalam situasi yang sulit, dan hal tersebut berhubungan dengan optimisme (Applebaum, dkk., 2014).

Berdasarkan penjelasan yang telah dipaparkan, maka hipotesis yang diajukan ialah ada peranan dukungan sosial terhadap optimisme. Penelitian ini diharapkan dapat memberikan manfaat, yaitu: menjadi tambahan keilmuan untuk kajian psikologi positif, serta membantu keluarga pasien dan instansi rumah sakit dalam memberikan dukungan kepada pasien.

\section{METODE}

Populasi dalam penelitian ini adalah semua orang yang terdiagnosis kanker atau cancer survivor yang sedang menjalani perawatan (rawat jalan maupun rawat inap) di RSI Siti Khadijah Palembang berusia 10-75 tahun, dengan jumlah 93 orang. Peneliti menggunakan teknik sampling jenuh, sehingga semua populasi sebanyak 93 orang cancer survivor dijadikan sebagai sampel.

Penelitian ini menggunakan dua skala psikologi yaitu skala optimisme dan skala dukungan sosial. Peneliti menyusun sendiri skala optimisme dengan bentuk skala Likert berdasarkan dimensi yang dikemukakan oleh Seligman (2006) yaitu, permanent, 
perpasiveness dan personalization, terdiri dari 22 aitem (11 aitem favorable dan 11 aitem unfavorable). Koefisien validitas skala optimisme ini diantara 0.309 sampai 0.597 , dan koefisien alpha reliabilitas sebesar 0.878. Peneliti menyusun skala dukungan sosial dengan bentuk Likert berdasarkan jenis-jenis dukungan sosial yang dikemukakan oleh House (Smet, 1994) yaitu dukungan emosional, dukungan penghargaan, dukungan instrumental dan dukungan informatif, terdiri dari 24 aitem (12 aitem favorable dan 12 aitem unfavorable). Koefisien skala skala ini antara 0.306 sampai 0.637, dan koefisien reliabilitas alpha sebesar 0.886 . Uji hipotesis dalam penelitian ini menggunakan teknik analisi regresi sederhana.

\section{HASIL}

Jumlah subjek dalam penelitian kali ini berjumlah 93 subjek yang dideskripsikan berdasarkan jenis kelamin, usia dan jenis kanker yang diderita. Berdasarkan jenis kelamin, jumlah subjek penelitian dengan jenis kelamin laki-laki 22 subjek $(23,66 \%)$ dan perempuan 71 subjek (76.43\%). Berdasarkan usia pada penggolongan usia remaja (11-20 tahun) 2 subjek (2,15\%), dewasa muda (21-40 tahun) 21 subjek (22,58\%), dewasa tengah (42-65 tahun) 64 subjek $(68,82 \%)$ dan dewasa akhir (66-lanjut usia) 6 subjek $(6,45 \%)$.

\section{Tabel 1.}

Deskripsi Kategorisasi Optimisme pada Subjek Penelitian

\begin{tabular}{|c|c|c|c|}
\hline Skor & Kategori & Frekuensi & Presentase \\
\hline$X<44$ & Rendah & 0 & $0 \%$ \\
\hline $44 \leq X<66$ & Sedang & 13 & $13.98 \%$ \\
\hline$X \geq 66$ & Tinggi & 80 & $86.02 \%$ \\
\hline \multicolumn{2}{|c|}{ Jumlah } & 93 & $100 \%$ \\
\hline
\end{tabular}

Berdasarkan hasil kategorisasi pada tabel 1, diketahui bahwa subjek dengan optimisme rendah adalah sebanyak 13 orang (13.98\%) dan optimisme tinggi sebanyak 80 orang $(86.02 \%)$.

Tabel 2.

Deskripsi Kategorisasi Dukungan Sosial pada Subjek Penlitian

\begin{tabular}{|c|c|c|c|}
\hline Skor & Kategori & Frekuensi & Presentase \\
\hline $\mathrm{X}<48$ & Rendah & 0 & $0 \%$ \\
\hline $48 \leq X<72$ & Sedang & 12 & $12,90 \%$ \\
\hline$X \geq 72$ & Tinggi & 81 & $87,10 \%$ \\
\hline \multicolumn{2}{|c|}{ Jumlah } & 93 & $100 \%$ \\
\hline
\end{tabular}

Berdasarkan hasil kategorisasi tabel 2, diketahui bahwa subjek dengan dukungan sosial rendah adalah sebanyak 12 subjek $(12,90 \%)$ dan dukungan sosial tinggi sebanyak 81 subjek $(87,10 \%)$.

Uji hipotesis yang digunakn adalah analisis regresi sederhana. Dan diperoleh signifikansi $0,000(\mathrm{p}<0,05)$ dan nilai $\mathrm{F}$ variabel optimisme dan dukungan sosial sebesar 62,791 , serta besarnya presentase pengaruh variabel bebas dukungan sosial terhadap variabel terikat 
optimisme (R Square) sebesar 0,408. Hal tersebut menunjukkan bahwa besar peranan variabel dukungan sosial terhadap variabel optimisme adalah 40,8\%, sedangkan sisanya adalah kontribusi variabel lain. Dengan demikian hipotesis dalam penelitian ini diterima, yaitu ada peranan dukungan sosial terhadap optimisme.

\section{DISKUSI}

Hasil analisis menggunakan teknik analisis regresi sederhana berdasarkan data yang didapatkan dari subjek cancer survivor yang berada di Rumah Sakit Islam Siti Khadijah Palembang terkait dengan variabel bebas dukungan sosial dan variabel terikat optimisme, diperoleh taraf siginifikansi sebesar $0,000(p<0,05)$ dengan nilai $R$ square sebesar 0,408 . Dengan demikian dapat disimpulkan bahwa hipotesis dalam penelitian ini diterima, yaitu ada peranan dukungan sosial terhadap optimisme pada cancer survivor yang berada di Rumah Sakit Islam Siti Khadijah Palembang.

Hasil penelitian ini sejalan dengan penelitian yang dilakukan oleh Khalid (2011) yang menyatakan bahwa ada pengaruh positif dukungan sosial terhadap optimisme hidup, dan dukungan sosial menyumbang sebesar $20,4 \%$ optimisme hidup pada penderita HIV dan AIDS. Selain itu, berdasarkan penelitian Ozka dan Ogze (2008) menunjukkan bahwa dukungan sosial dan stres sebagai faktor dominan yang mempengaruhi optimisme kesembuhan pasien kanker payudara. Dukungan sosial membuat individu menjadi lebih siap dan optimis dalam menyikapi persoalan sehingga akan lebih mudah menghadapi masalah dan akan lebih kecil kemungkinan mengalami stres dan depresi (Smet, 1994).

Selanjutnya hasil analisis pada variabel bebas diperoleh nilai $\mathrm{R}$ square sebesar 0,408 yang menunjukkan peranan dukungan sosial terhadap optimisme pada cancer survivor di Rumah Sakit Islam Siti Khadijah Palembang adalah sebesar 40,8\%, sedangkan sisanya $59,2 \%$ adalah kontribusi dari variabel lainnya.

Berdasarkan penelitian Karademas, dkk., (Wardiyah, Afiyanti \& Budiati, 2017) diketahui bahwa selain dukungan sosial, optimisme terhadap kesembuhan dan kesehatan pasien dipengaruhi oleh beberapa faktor diantaranya seperti umur, status paritas, tingkat pendidikan, status perkawinan, harga diri, status kesehatan, stress, koping serta self efficacy. Selain itu, berdasarkan penelitian Scheir, dkk., dan Chamberlin, dkk., (Smet, 1994) bahwa optimisme dikaitkan dengan kesembuhan lebih cepat dari berbagai jenis pembedahan dan lebih menggunakan problem focused coping, mencari dukungan sosial, dan menekankan aspek-aspek positif dari situasi yang penuh tekanan.

Vinacle (Hasan, Lilik \& Agustin, 2013) menyatakan bahwa terdapat dua faktor yang mempengaruhi pola pikir optimisme dan pesimisme yaitu faktor etnosentris (faktor dari luar diri) yang meliputi keluarga, status sosial, jenis kelamin, agama, kebudayaan dan sebagainya, dan faktor egosentris (faktor dari dalam diri) yang meliputi sifat dan aspek kepribadian yang dimiliki individu.

Selanjutnya, peneliti melakukan analisis deskripsi terhadap kategorisasi optimisme pada penelitian ini diperoleh frekuensi paling banyak pada kategori tinggi yaitu sebanyak 80 orang $(86,02 \%)$ dan kategori rendah sebanyak 13 orang $(13,98 \%)$. Berdasarkan hal tersebut, diketahui bahwa subjek penelitian memiliki optimisme yang tinggi, didukung 
oleh penelitian yang dilakukan oleh Hatifah dan Nirwana (2014) bahwa optimisme membawa pengaruh bagi kesehatan, meningkatkan kesehatan secara psikologis, memiliki perasaan yang baik, melakukan penyelesaian masalah dengan cara yang logis sehingga hal ini dapat meningkatkan kekebalan tubuh. Selain itu, didukung penelitian yang dilakukan oleh Sharot (Blackwell, dkk., 2013) bahwa partisipan penelitiannya yang memiliki tingkat optimisme yang tinggi dikarenakan partisipannya cenderung mengharapkan kejadian baik dan membayangkan akan terjadi padanya dibandingkan pada kejadian buruk, dan lebih cenderung membayangkan dengan perasaan yang positif dan lebih baik.

Selanjutnya peneliti melakukan analisa deskriptif pada variabel dukungan sosial, didapatkan kategorisasi variabel dukungan sosial berada pada kategori tinggi sebanyak 81 orang $(87,10 \%)$ dan kategori sedang sebanyak 12 orang $(12,90 \%)$. Hal ini menunjukkan bahwa cancer survivor yang berada di Rumah Sakit Islam Siti Khadijah Palembang memiliki dukungan sosial yang tinggi. Berdasarkan penelitian yang dilakukan oleh Mattson (2011) bahwa dukungan sosial tidak hanya membantu individu merasa lebih baik atau membantu dalam mengatasi tantangan, namun juga dukungan sosial mampu mengarah keperbaikan kesehatan, termasuk kesehatan fisik, kesehatan psikologis, dan kesejahteraan secara keseluruhan. Lebih lanjut, Ozkan dan Ogze (2008) menyatakan bahwa dukungan sosial dari orang-orang terdekat, teman dan petugas kesehatan memberikan arti khusus bagi kesembuhan responden.

Hal ini selaras dengan penelitian yang dilakukan oleh Frahm dan Sari (Caesendri \& Sri, 2015) yang menyatakan bahawa keluarga merupakan teman terbaik bagi penderita kanker untuk sama-sama berjuang melawan penyakitnya. Selain itu, Friedman (Anggina, Hamzah \& Pandhit, 2010) dalam penelitiannya menjelaskan bahwa efek dari dukungan sosial yang diberikan keluarga terhadap kesehatan berfungsi secara bersamaan dan berpengaruh positif dukungan sosial dari keluarga adalah penyesuaian pada kejadian dalam kehidupan yang penuh dengan stres.

Ada peranan dukungan sosial terhadap optimisme dalam penelitian ini terlihat dari penjelasan diatas deskripsi data penelitian yang menunjukkan bahwa tingkat optimisme dan dukungan sosial pada cancer survivor di Rumah Sakit Islam Siti Khadijah Palembang secara umum adalah tinggi. Hal ini selaras dengan hasil penelitian yang dilakukan oleh Mustika, Wijayanti dan Lilik (2014) bahwa semakin tinggi tingkat dukungan sosial menyebabkan semakin tinggi pula tingkat optimisme dalam pengambilan berwirausaha pada remaja penyandang cacat tubuh di BBRSBD Prof. Dr. Soeharso Surakarta.

Berdasarkan hasil analisis data dan teori yang telah dipaparkan diatas, bahwa dukungan sosial memberikan kontribusi yang cukup besar terhadap optimisme. Hal ini menandakan bahwa dukungan sosial merupakan salah satu faktor yang mempengaruhi optimisme.

\section{SIMPULAN DAN IMPLIKASI}

Berdasarkan pembahasan dan hasil analisis penelitian, maka disimpulkan hipotesis penelitian ini diterima yaitu ada peranan dukungan sosial terhadap optimisme pada 
cancer survivor di Rumah Sakit Islam Siti Khadijah Palembang. Bagi cancer survivor, hendaknya selalu merasa optimisme dan terus menjalani pengobatan hingga selesai walaupun selama masa pengobatan mengalami perubahan dan penurunan fisik serta psikis. Keluarga juga hendaknya meningkatkan pemberian dukungan baik binstrumental, emosional, penghargaan dan informasi seperti membantu cancer survivor dalam perawatan, memberikan perhatian dan mendampingi cancer survivor untuk melawan dan menjalani hari-harinya sebagai cancer survivor sehingga cancer survivor tetap optimisme mencapai kesembuhan.

Bagi instansi tempat penelitian, Rumah Sakit Islam Siti Khadijah Palembang hendaknya meningkatkan fasilitas dan pelayanan khususnya seperti penambahan jumlah kamar rawat inap serta penyediaan obat yang sebaiknya tersedia sesuai dengan jadwal kemoterapi pasien hal ini merupakan bentuk dukungan instrumental. Selain itu, hendaknya Rumah Sakit memberikan dukungan informasi dengan cara pada bagian poliklinik Rumah Sakit menyediakan fasilitas informasi berupa penyuluhan terkait upaya deteksi dini maupun antisipasi, pengenalan kanker, proses, efek samping terapi, dan lainlainn, serta hendaknya instansi menyediakan fasilitas self helf group, cognitive therapy, supportive therapy untuk cancer survivor dalam mengatasi masalah psikososial pasien sehingga dapat berdampak baik dalam penyembuhan pasien kanker.

Bagi penelitian selanjutnya diharapkan dapat memperluas ruang lingkup penelitian seperti meneliti variabel lain yang memungkinkan mempengaruhi optimisme pada cancer survivor. Selain itu, dalam pembuatan aitem skala menggunakan pilihan kata-kata yang memungkinkan untuk meminimalkan terjadinya sosial desirable dan pada pembuatan alat ukur dukungan sosial dapat juga menggunakan teori tokoh-tokoh lain dikarenakan cukup banyaknya tokoh yang mengemukakan teori dukungan sosial, namun tetap menyesuaikan dengan penelitian. Selanjutnya, hendaknya penelitian dilakukan dengan waktu yang seefektif mungkin mengingat subjek penelitian ini merupakan pasien terminal illness.

\section{REFERENSI}

Anggina, L. L., Hamzah, A., \& Pandhit. (2010). Hubungan antara dukungan sosial keluarga dengan kepatuhan pasien diabetes mellitus dalam melaksanakan program diet di poli penyakit dalam RSUD Cibabat Cimahi. Jurnal Penelitian Kesehatan Suara Forikes, 1(2), 1-9.

American Cancer Society. (2015). Cancer treatment and survivorship fact and figure. American Cancer Society Inc.

Apllebaum, A. J., Stein, E. M., Lord-Bessen, J., Pessin, H., Rosenfeld, B., \& Breitbart, W. (2014). Optimism, sosial support, and health outcomes in patients with advanced cancer. National Institute of Health: Psychooncology. 23(3), 299306. doi:10.1002/pon.3418.

Blackwell, S. E., Rius-Ottenheim, N., W. M, Yv., Maaren, S., Carlier, I. V. E., Middlekoop, V. D., Zitam, F. G., Spihoven, P., Holmes, E. A., \& Giltay, E. J. (2013). Optimism and mental imagery: A possible cognitive marker top promote well-being?. Psychiatry Research, Elsevier Ireland Ltd, 206, 56-61. doi: 10.1016/j.psychres. 
Canaria, D. J. A., Prichard, I., Hutchinson, A. D., \& Wilson, C. (2016). Fear of cancer recurrence and psychological well-being in woman with breast cancer: The role of causal cancer attributions and optimism. European Jurnal of Cancer Care, 1-12. doi: 10.1111/ecc.12579.

Forgeard, M. J. C., \& Seligman, M. (2012). Seeing the glass galf full: The review of consequences of optimism. Pratiques Psychologiques, 18, 107-120.

Ghufron, M. N., \& Risnawarti, R. (2010). Teori-teori psikologi. Yogyakarta: Ar-ruzz Media.

Hasan, A., Lilik, S., \& Agustin, R. W. (2013). Hubungan antara penerimaan diri dan dukungan emosi dengan optimisme pada penderita diabetes mellitus anggota aktif persada (persatuan diabetes indonesia) cabang Surakarta. Jurnal Ilmiah Psikologi Candrajiwa, 2(2), 60-72.

Harvey, J., Dittus, K., \& Mench, E. (2017). Ehealth and behavioral weight loss for female cancer survivors: A review. Women Health Journal Sage Publication, 20, 1-9. doi: 10.1177/1745505717731012.

Hatifah, S., \& Nirwana, D. (2014). Pemahaman hadis tentang optimisme. Studio Insania, 2(2), 115-130.

Idham, K. (2011). Pengaruh self esteem dan dukungan sosial terhadap optimisme hidup penderita HIV/AIDS (Skripsi). Universitas Islam Negeri Syarif Hidayatullah, Jakarta.

Kementrian Kesehatan RI. (2015). Infodatin: pusat dan informasi kementrian kesehatan RI "situasi penyakit kanker". Jakarta Selatan: Kementrian Kesehatan RI Pusat Data dan Informasi.

Kemenkes RI. (2017a). Kementrian kesehatan ajak dan kendalikan kanker (online). Retrieved from http://www.depkes.go.id/article/print/17020200002/kementerian-kesehatanajak-masyarakat-cegah-dan-kendalikan-kanker.html.

Kemenkes RI. (2017b). Data dan informasi profil kesehatan Indonesia. Jakarta: Pusat Data Informasi Kementrian Kesehatan RI.

Lidya, M. (2013). Hubungan optimisme dan kualitas hidup pada penderita kanker payudara. (Naskah Publikasi). Fakultas Psikologi Universitas Indonesia, Depok.

Lusiatun, M., Ambar., \& Murti, B. (2016). The effects of self-efficacy, family support, and socio-economic factors on the quality of Life of patients with breast cancer at Dr. Moewardi Hospital Surakarta. Fakultas Kedokteran Universitas Sebelas Maret, Surakarta.

Malpass, J. K, Mihalko, S. L., Russel, G., Case, D., Miller, B., \& Avis, N. E. (2017). Problem experienced by ovarian cancer survivors during treatment. The Association of Women Health, Obstretic and Neonatal Nurses, 04(134), 1-9. doi: 10.1016/j-jogn.2017.04.134. 
Mattson, M., Hall, J. G. (2011). Linking health communication with social support. USA: Kendall Hunt Publishing Co.

Mustika, A., Wijayanti, S., \& Lilik, S. (2014). Hubungan antara dukungan sosial dan adversity intelligence dengan optimisme dalam pengambilan keputusan berwirausaha. Jurnal Ilmiah Psikologi Candrajiwa, 3(1), 1-10.

National Cancer Institute. (2017). Cancer (online). Retrieved from https://www.cancer.gov/publications/dictionaries/cancer-terms.

Nurthjanjanti, H., \& Ratnaningsih, I. Z. (2011). Hubungan kepribadian hardiness dengan optimisme pada calon tenaga kerja Indonesia (CTKI) wanita di BLKLN Disnakertrans Jawa Tengah. Jurnal Psikologi Undip, 10(2), 126-132.

Ozkan, S., \& Ogze, F. (2008). Impotance of social support for functional status in breast cancer patients. Asian of Pacific Journal Prevention, 9, 601-604.

Prastiwi, T. P. (2012). Kualitas hidup penderita kanker. Developmental And Clinical Psychology, 1(1), 21-26.

Sarafino, E. P. M., (2011). Health psychology: Biopsychosocial interaction (7th ed.). United States of the America: Jonh Wiley \& Son, Inc.

Seligman, E. P. M. (2006). Learned optimism: How to change your mind and your life. New York: A Division Random House, Inc.

Smet, B. (1994). Psikologi kesehatan. Jakarta: Grasindo.

Wardiyah, A., Afiyanti, Y., \& Budiati, T. (2017). Faktor yang mempengaruhi optimisme kesembuhan pada pasien kanker payudara. Jurnal Keperawatan Fakultas Ilmu Keperawatan Universitas Indonesia, 5(2), 121-127.

WHO. (2017). Cancer (online). Retrieved from http://www.who.int/cancer/en/.

WHO. (2017). Key facts cancer (online). Retrieved from http://www.who.int/mediacentre/factsheets/fs297/en/.

Yudissanta, A., \& Ratna, M. (2012). Analisis pemakaian kemoterapi pada kasus kanker payudara dengan menggunakan metode regresi logistik multinominal (Studi Kasus Pasien di Rumah Sakit X Surabaya). Jurnal Sains dan Seni ITS, 1(1), 112-117. 